\title{
Keterampilan Berpikir Kreatif Pada Siswa Sekolah Menengah Di Palangka Raya Menggunakan Pendekatan Saintifik
}

\author{
Hadma Yuliani $^{1}$, Mariati ${ }^{2}$, Resa Yulianti ${ }^{3}$, Cici Herianto ${ }^{4}$ \\ 1,2,3,4 Program Studi Tadris Fisika, Institut Agama Islam Negeri Palangka Raya \\ Email : ${ }^{1}$ hadma.yuliani@iain-palangkaraya.ac.id
}

Received January 27, 2017; Revised March 20, 2017; Accepted March 29, 2017

\begin{abstract}
Abstrak
Penelitian ini bertujuan untuk mengetahui peningkatan kemampuan berpikir kreatif siswa di sekolah menengah di palangka raya menggunakan pendekatan saintifik yang menggunakan model pembelajaran CLIS (Children's Learning in Science), inkuiri terbimbing, metode eksperimen pada pembelajaran fisika pokok bahasan pesawat sederhana. Penelitian ini menggunakan pendekatan kuantitatif dan jenis penelitiannya adalah deskriptif. Instrumen yang digunakan adalah tes berpikir kreatif pada materi pesawat sederhana untuk pelajaran fisika. Populasi dalam penelitian ini adalah seluruh Sekolah Menengah Pertama di Kota Palangka Raya. Didalam mengambil sampel menggunakan teknik cluster sampling yaitu MTs AnNur Palangka Raya dan SMP Negeri 7 Palangka Raya. Sampel penelitian yaitu kelas VIII-A, dan VIII B untuk MTs An-Nur Palangka Raya, dan kelas VIII - B di SMP 7 Palangka Raya. Hasil penelitian ini dapat disimpulkan peningkatan kemampuan berpikir kreatif siswa di Palangka Raya setelah diterapkan pendekatan Saintifik dengan menggunakan model pembelajaran CLIS (Children's Learning in Science) diperoleh $\mathrm{N}$-Gain rata-rata adalah 0,45 , dengan inkuiri terbimbing diperoleh $\mathrm{N}$-gain rata-rata sebesar 0,34 , dengan metode eksperimen diperoleh $\mathrm{N}$-gain 0,40. Jadi, peningkatan kemampuan berpikir kreatif siswa di sekolah menengah di palangka raya menggunakan pendekatan saintifik yang menggunakan model pembelajaran CLIS (Children's Learning in Science), inkuiri terbimbing, metode eksperimen pada pembelajaran fisika pokok bahasan pesawat sederhana dalam kategori sedang.
\end{abstract}

Kata Kunci: Keterampilan Berfikir Kreatif, Pendekatan Saintifik

\section{Creative Thinking Skills At Secondary School Students In Palangka Raya Using The Scientific Approach}

\section{Abtract}

This study aims to determine the improvement of students' creative thinking ability in secondary schools at Palangka Raya using a scientific approach that uses CLIS (Children's Learning in Science) learning model, guided inquiry, an experimental method of basic physics lesson study. This research uses quantitative approach and the research type is descriptive. The instrument used is a test of creative thinking on simple plane materials for physics lessons. The population in this research is all of Junior High School in Palangka Raya City. In taking samples using cluster sampling technique that is MTs AnNur Palangka Raya and SMP Negeri 7 Palangka Raya. The research sample is class VIII-A, and VIII-B for MTs An-Nur Palangka Raya, and class VIII - B at SMP 7 Palangka Raya. The result of this research can be concluded the improvement of students' creative thinking ability in Palangka Raya after the applied scientific approach by using CLIS learning model (Children's Learning in Science) obtained N-Gain average is 0.45 , with guided inquiry, obtained the average $\mathrm{N}$-gain Of 0.34 , with the experimental method, 


\section{Jurnal Pendidikan Fisika dan Keilmuan (JPFK) Vol 3 No 1 Maret 2017, hal 48-56 Avaliable online at : http://e-journal.unipma.ac.id/index.php/JPFK \\ Print ISSN: 2442-8868, Online ISSN: 2442-904x}

obtained N-gain 0.40. Thus, the improvement of students' creative thinking skills in secondary schools at the Palangka Raya uses a scientific approach that uses the CLIS (Children's Learning in Science) learning model, guided inquiry, experimental methods on simple plane subject matter physics in a moderate category.

Keywords: Creative Thinking Skills, Scientific Approach

\section{PENDAHULUAN}

Fisika berasal dari bahasa yunani yang berarti "alam". Fisika merupakan ilmu pengetahuan yang mempelajari benda-benda di alam, gejala-gejala, kejadian-kejadian alam serta interaksi dari benda-benda di alam tersebut (Ganijanti, aby sarojo, 2002). Gejala-gejala tersebut pada umumnya adalah apa yang dialami oleh indera kita, misalnya penglihatan, menemukan optika cahaya, pendengaran menemukan bunyi, panas juga dapat diamati melalui indera perasaan.

Fisika merupakan bagian dari Ilmu Pengetahuan Alam (IPA) yang merupakan usaha sistematis dalam rangka membangun dan mengorganisasikan pengetahuan dalam bentuk penjelasan-penjelasan yang dapat diuji dan mampu memprediksi gejala alam. Memprediksi gejala alam diperlukan kemampuan pengamatan yang dilanjutkan dengan penyelidikan melalui kegiatan metode ilmiah (Toharudin dkk, 2011). Ilmu Fisika merupakan (1) proses memperoleh informasi melalui metode empiris (empirical method); (2) informasi yang diperoleh melalui penyelidikan yang telah ditata secara logis dan sistematis; dan (3) suatu kombinasi proses berpikir kritis yang menghasilkan informasi yang dapat dipercaya dan valid.

Berdasarkan wawancara dengan guru mata pelajaran fisika di MTs An-Nur Palangka Raya bahwa strategi yang digunakan dalam kegiatan pembelajaran IPA mereka sangat jarang sekali menggunakan metode eksperimen dan melakukan percobaan/eksperimen untuk membuktikan konsep fisika karena Laboratorium fisika dipakai untuk ruangan kelas. Siswa di MTs An-Nur Palangka Raya saat diwawancarai mengatakan mereka merasa kurang termotivasi dalam kegiatan belajar mengajar IPA khususnya fisika. Hal ini disebabkan karena pelajaran fisika selalu menekankan hapalan rumus dan pemahaman konsep yang sulit, serta penggunaan metode pembelajaran ceramah yang sering dijumpai membuat mereka mudah merasa bosan bahkan mereka mengatakan tidak pernah melakukan percobaan/eksperimen (Wawancara Guru; tanggal 25/09/2014).

Obsevasi awal juga dilakukan peneliti di SMP Negeri 7 Palangka Raya. Rendahnya hasil belajar dipengaruhi oleh banyak faktor, salah satunya adalah pemilihan strategi pembelajaran. Selain rendahnya nilai hasil belajar para siswa, terlihat bahwa keaktifan siswa dalam mengikuti kegiatan proses belajar mengajar kurang aktif khususnya pada mata pelajaran fisika. Siswa merasa kurang termotivasi dalam kegiatan belajar mengajar IPA khususnya fisika. Hal ini disebabkan karena pelajaran fisika selalu menekankan hapalan rumus dan pemahaman konsep yang sulit (Observasi di SMP Negeri 7 Palangkaraya, bulan Maret 2016).

Kondisi pembelajaran yang ada sebelumnya hendaknya diperbaiki, salah satunya dengan menggunakan pendekatan keterampilan proses (Yuliani et al., 2012), menggunakan variasi model pembelajaran seperti model Kooperatif (Kumala Sari, Supriatin, dan Yuliani, 2015), model Learning Cycle (Astupura dan Yuliani, 2015; 2016), serta pendekatan pembelajaran saintifik (Saregar, 2016).

Pembelajaran menggunakan pendekatan saintifik merupakan pembelajaran yang menggunakan pendekatan ilmiah dan inkuiri, siswa berperan secara langsung baik secara individu maupun kelompok untuk menggali konsep dan prinsip selama kegiatan pembelajaran, sedangkan tugas guru adalah mengarahkan proses belajar yang dilakukan siswa dan memberikan koreksi terhadap konsep dan prinsip yang didapatkan siswa (Marjan,2014).

Pengertian pembelajaran pendekatan saintifik, maka fisika sebagai produk dan proses, sangat cocok untuk diajarkan mengunakan 


\section{Jurnal Pendidikan Fisika dan Keilmuan (JPFK) Vol 3 No 1 Maret 2017, hal 48-56}

Avaliable online at : http://e-journal.unipma.ac.id/index.php/JPFK

Print ISSN: 2442-8868, Online ISSN: 2442-904x

pembelajaran pendekatan saintifik, Pendekatan saintifik memiliki hubungan erat dengan pembelajaran sains fisika karena pendekatan pembelajaran ini menekankan pada keaktifan siswa dalam belajar, serta memberikan kesempatan kepada siswa untuk membangun konsep dalam pengetahuannya secara mandiri, membiasakan siswa dalam merumuskan, menghadapi, dan menyelesaikan permasalah yang ditemukan.

Ide atau gagasan awal siswa tentang suatu masalah tertentu dalam pembelajaran dapat muncul diperlukan suatu proses berpikir yang menuntut keseimbangan dan aplikasi dari ketiga aspek esensial, yaitu kecerdasan analitis, kreatif dan praktis. Aspek-aspek tersebut yang ketika digunakan secara kombinatif dan seimbang akan melahirkan kecerdasan kesuksesan yang disebut dengan berpikir kreatif (Riyanto, 2009). Penguasaan konsep pada pembelajaran fisika dapat meningkat dengan meningkatnya berpikir kreatif siswa, khususnya pada materi Pembelajaran Fisika.

Berpikir kreatif adalah sebuah kebiasaan dari fikiran yang dilatih dengan memperhatikan intuisi, menghidupkan imajinasi, mengungkapkan kemungkinan-kemungkinan baru. Berfikir kreatif merupakan hal intrinsik yang perlu digali karena aspek kreatif merupakan salah satu dari tujuan pendidikan nasional yang dicantumkan didepan, sehingga penting untuk melakukan berbagai hal terencana dalam peningkatan berpikir kreatif (Johnson, 2011).

Berdasarkan uraian pada latar belakang, maka dapat diambil rumusan penelitian sebagai berikut untuk Bagaimana peningkatan kemampuan berpikir kreatif siswa di sekolah menengah di palangka raya menggunakan pendekatan saintifik yang menggunakan model pembelajaran CLIS (Children's Learning in Science), inkuiri terbimbing, metode eksperimen pada pembelajaran fisika pokok bahasan pesawat sederhana Pada Sekolah Menengah Pertama di Palangka Raya.

Pendekatan saintifik berkaitan erat dengan metode saintifik. Metode saintifik (ilmiah) pada umumnya melibatkan kegiatan pengamatan atau observasi yang dibutuhkan untuk perumusan hipotesis atau mengumpulkan diperoleh melalui pengamatan atau percobaan. Oleh karena itu kegiatan percobaan dapat diganti dengan kegiatan memperoleh informasi dari berbagai sumber. Pembelajaran dengan integrasi kegiatan ilmiah pada umumnya merupakan kegiatan inkuiri, yaitu proses berberpikir untuk memahami tentang sesuatu dengan mengajukan pertanyaan. pendekatan saintifik (scientific approach) dalam pembalajaran yang memiliki komponen proses pembelajaran antara lain: 1) mengamati; 2) menanya; 3) mencoba/mengumpulkan informasi; 4) menalar/asosiasi; dan 5) membentuk jejaring (melakukan komunikasi) (Sani, 2014).

Berpikir lebih kreatif tidak akan lahir secara tiba-tiba tanpa adanya kemampuan. Keingintahuan yang tinggi dan diikuti dengan keterampilan dalam membaca. Seperti yang diungkapkan oleh Porter dan Hernacki bahwa seorang yang kreatif selalu mempunyai rasa ingin tahu, ingin mencoba-coba bertualang secara intuitif (Hamzah dan Nurdin, 2014).

Kreatif berarti memiliki daya cipta atau menciptakan hal baru. Istilah kreatif memiliki makna bahwa pembelajaran merupakan sebuah proses mengembangkan kreativitas siswa, karena pada dasarnya setiap individu memiliki imajinasi dan rasa ingin tahu yang tidak pernah berhenti menurut para ahli kreativitas itu merupakan kemampuan seseorang melahirkan sesuatu yang baru atau kombinasi hal yang sudah ada hingga terkesan baru (Ngalimun, 2013). Jadi pembelajaran kreatif adalah pembelajaran yang mampu menciptakan peserta didik lebih aktif, berani menyanpaikan pendapat dan berargumen, menyampaikan masalah atau sulusinya serta memperdayakan semua potensi yang sudah tersedia.

Berpikir biasanya diasumsikan sebagai proses kognitif, suatu tindakan mental dengan pengetahuan yang dimilikinya sebagaimana berfikir dapat dibedakan kedalam ciri kognitif dan nonkognitif kedalam ciri kognitif termasuk empat cara berfikir kreatif yaitu orisinalitas, flexibelitas, kelancaran dan elaborasi. Dalam ciri nonkognitif sama pentingnya dengan ciri-ciri kognitif karena tanpa ditunjang oleh kepribadian yang sesuai kreatifitas seseorang tidak akan berkembang secara wajar.

Kecerdasan dan kreatifitas sering kali dihubungkan kreatif lebih bersifat intuitif atau 


\section{Jurnal Pendidikan Fisika dan Keilmuan (JPFK) Vol 3 No 1 Maret 2017, hal 48-56 \\ Avaliable online at : http://e-journal.unipma.ac.id/index.php/JPFK \\ Print ISSN: 2442-8868, Online ISSN: 2442-904x}

konvergen sedangkan kecerdasan analitif lebih bersifat logis atau divergen. Pendapat yang mengatakan bahwa siswa yang tingkat kecerdasannya tinggi berbeda-beda kreatifitasnya dan siswa yang kreatifitasnya tinggi berbeda-beda pula kecerdasannya, hal ini karena berfikir analisis dan berfikir kreatif berbeda. Siswa yang tinggi tingkat kecerdasannya tidak selalu menunjukan tingkat kreatifitas yang tinggi dan banyak siswa yang tinggi kreatifitasnya tidak selalu tinggi tingkat kecerdasannya (Riyanto, 2010).

Tabel 1. Indikator Berpikir Kreatif (Nursito, 2000):

\begin{tabular}{|c|c|c|}
\hline No & Indikator & Perilaku \\
\hline 1 & $\begin{array}{l}\text { Kemampuan berpikir lancar } \\
\text { (Fluency). }\end{array}$ & $\begin{array}{l}\text { Mengajukan banyak pertanyaan, kemampuan mengemukakan } \\
\text { ide-ide yang serupa untuk memecahkan suatu masalah. }\end{array}$ \\
\hline 2 & $\begin{array}{l}\text { Kemampuan berpikir luwes } \\
\text { (Flexibility). }\end{array}$ & $\begin{array}{l}\text { Memberikan bermacam-macam penafsiran (interpretasi) } \\
\text { terhadap suatu gambar. }\end{array}$ \\
\hline 3 & $\begin{array}{l}\text { Kemampuan berpikir orisinil } \\
\text { (Originality). }\end{array}$ & $\begin{array}{l}\text { Memberikan bermacam-macam penafsiran (interpretasi) } \\
\text { terhadap suatu masalah. }\end{array}$ \\
\hline 4 & $\begin{array}{l}\text { kemampuan merinci } \\
\text { (Elaboration). }\end{array}$ & $\begin{array}{l}\text { Memikirkan hal-hal yang tak pernah terpikirkan oleh orang lain } \\
\text { Mengembangkan atau memperkaya gagasan orang lain. } \\
\text { Menyusun langkah-langkah secara terperinci. }\end{array}$ \\
\hline
\end{tabular}

Indikator berpikir kreaktif pada ranah kognitif adalah sebagai berikut :

1. Kemampuan berpikir lancar (Fluency)

Kemampuan berfikir lancar (Fluency) adalah siswa dapat mengajukan banyak pertanyaan dan mampu mengemukan ide-ide yang serupa untuk memecahkan suatu masalah. Contohnya, siswa diberikan beberapa peristiwa yang berhubungan dengan konsep pesawat sederhana. Kemudian dari peristiwa tersebut siswa dapat mengemukakan gagasan dan membuat pertanyaaan.

2. Kemampuan berfikir luwes (Flexibility)

Kemampuan berfikir luwes (Flexibility) adalah siswa dapat memberikan bermacammacam penafsiran terhadap suatu gambar. Contohnya, siswa diberikan suatu gambar tuas, kemudian dari gambar tuas tersebut siswa diberikan suatu masalah yang berhubungan dengan keuntungan tuas itu sendiri.

3. Kemampuan berfikir orisinil (Originality).

Berpikir orisinil (Originality) adalah siswa dapat memberikan bermacam-macam penafsiran terhadap suatu gambar dan memikirkan hal-hal
Proses berpikir kompleks dikelompokkan menjadi empat yaitu: pemecahan masalah, pengambilan sebagai kemampuan untuk membuat kombinasi dari pengetahuanpengetahuan yang dimiliki sehingga menghasilkan kombinasi yang sesuai untuk menyelesaikan masalah (Palaila, 2007). Dalam berfikir kompleks juga termasuk berfikir nonkognitif dan berfikir kognitif termasuk di dalamnya kriteria berfikir kreatif. yang tak pernah terpikirkan oleh orang lain. Contohnya, siswa diberikan suatu gambar permasalahan, sehingga dari permasalahan tersebut siswa menafsirkan gambar yang berbeda dengan jawaban teman yang lainnya tetapi konsepnya sama.

4. Kemampuan merinci (Elaboration)

Kemampuan merinci (Elaboration) siswa dapat mengembangkan atau memperkaya gagasan orang lain dan menyusun langkahlangkah secara terperinci. Contohnya, siswa membuat soal yang berkaitan dengan pesawat sederhana, kemudian dari soal tersebut siswa menjawab dengan caranya sendiri, dari jawaban tersebut diberikan penjelasan baik berupa hitungan maupun penjelasan berupa alasan yang lainnya yang dapat menguatkan jawaban yang dibuat siswa tersebut (Nursito, 2000).

Keempat indikator tersebut akan digunakan untuk merumuskan tujuan pembelajaran yang akan dicapai dalam mengukur kemampuan kreativitas berpikir siswa dengan tes tertulis, yaitu pada postest dan pretest yang terdiri dari soal-soal essay.

\section{METODE PENELITIAN}




\section{Jurnal Pendidikan Fisika dan Keilmuan (JPFK) Vol 3 No 1 Maret 2017, hal 48-56}

Avaliable online at : http://e-journal.unipma.ac.id/index.php/JPFK

Print ISSN: 2442-8868, Online ISSN: 2442-904x

Populasi dalam penelitian ini adalah seluruh Sekolah Menengah Pertama di Kota Palangka Raya. Didalam mengambil sampel menggunakan teknik cluster sampling, yaitu teknik sampling daerah digunakan untuk menentukan sampel bila obyek yang akan diteliti atau sumber data yang luas (Sugiyono, 2007). Menetapkan MTs An-Nur Palangka Raya dan SMP Negeri 7 Palangka Raya dengan kelas VIIIA, dan VIII - B untuk MTs An-Nur Palangka Raya, dan kelas VIII - B di SMP 7 Palangka Raya sebagai sampel penelitian. Penelitian ini dilaksanakan pada tahun ajaran 2015/2016.

Penelitian ini menggunakan pendekatan kuantitatif. Penelitian ini merupakan jenis penelitian deskriptif. Penelitian ini berusaha menjawab permasalahan yang diajukan penulis, yaitu tentang bagaimana peningkatan kemampuan berpikir kreatif siswa di Palangka Raya setelah diterapkan pendekatan Saintifik dengan menggunakan model pembelajaran CLIS (Children's Learning in Science), inkuiri terbimbing, metode eksperimen pada pembelajaran fisika pokok bahasan pesawat sederhana Pada Sekolah Menengah Pertama.

Teknik pengumpulan data yang digunakan dalam penelitian ini antara lain: metode tes untuk mengetahui kemampuan berfikir kreatif. Instrumen pengambilan data digunakan tes. Peningkatan hasil berpikir kreatif siswa dianalisis menggunakan n-gain untuk mengetahui peningkatan kemampuan berpikir kreatif siswa sesudah pembelajaran Fisika pada materi pesawat sederhana.

\section{HASIL DAN PEMBAHASAN}

Hasil peningkatan kemampuan berpikir kreatif siswa di Palangka Raya setelah diterapkan pendekatan Saintifik dengan menggunakan model pembelajaran CLIS (Children's Learning in Science), inkuiri terbimbing, metode eksperimen pada pembelajaran fisika pokok bahasan pesawat sederhana Pada Sekolah Menengah Pertama dijelaskan masing-masing kelas.

\section{Peningkatan kemampuan berpikir kreatif siswa di Palangka Raya setelah diterapkan pendekatan Saintifik dengan menggunakan model pembelajaran CLIS}

Peningkatan kemampuan berpikir kreatif siswa di Palangka Raya setelah diterapkan pendekatan Saintifik dengan menggunakan model pembelajaran CLIS diukur melalui tes tertulis sebelum dan setelah diterapkan model pembelajaran CLIS. Penelitian ini menggunakan sampel sebanyak 26 siswa yaitu siswa kelas VIIIB di Mts An-Nur Palangka Raya dengan model pembelajaran CLIS untuk meningkatkan kemampuan berpikir kreatif siswa. Hasil ratarata pretest berpikir kreatif adalah 23,48 dengan kategori sangat kurang kreatif dan rata-rata postest berpikir kreatif adalah 57,05 dengan kategori kurang kreatif dan Gain sebesar 33,57. Model pembelajaran CLIS pada materi pesawat sederhana, kemampuan berpikir kreatif siswa meningkat yaitu dapat terlihat dari hasil N-Gain rata-rata adalah 0,45 dengan kategori sedang yang ditunjukkan pada Gambar 1 berikut.

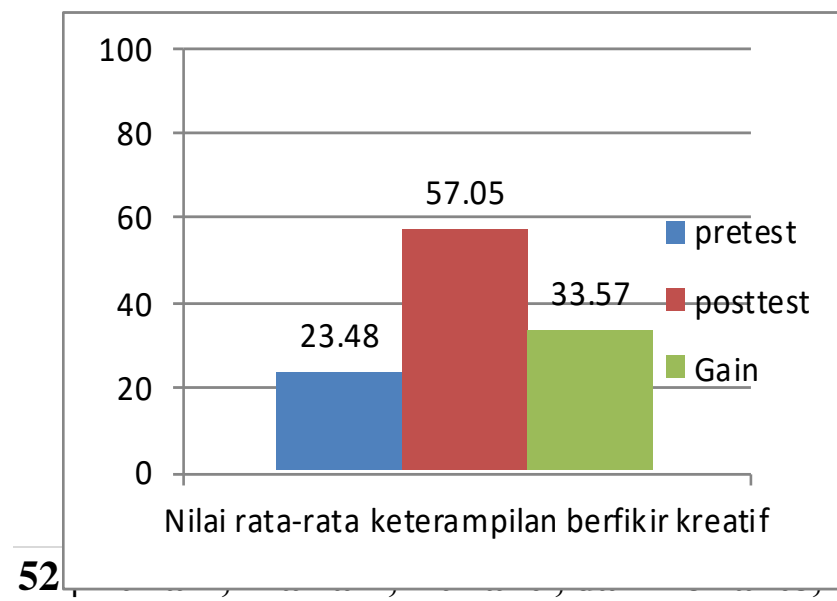


Jurnal Pendidikan Fisika dan Keilmuan (JPFK) Vol 3 No 1 Maret 2017, hal 48-56

Avaliable online at : http://e-journal.unipma.ac.id/index.php/JPFK

Print ISSN: 2442-8868, Online ISSN: 2442-904x

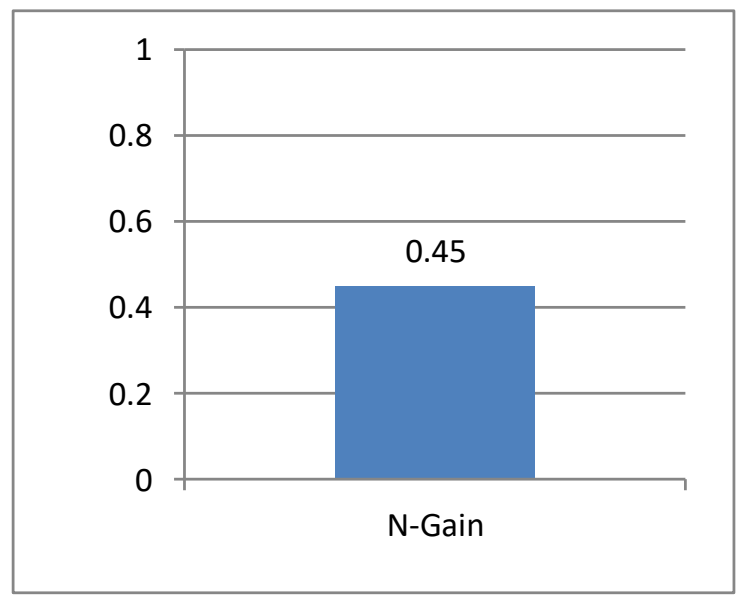

Gambar 1. Diagram Rata-rata nilai Pretest, Postest, Gain, dan N-gain Berpikir Kreatif Siswa diterapkan pendekatan Saintifik dengan menggunakan model pembelajaran CLIS

Gambar 1 menunjukkan Penerapan model pembelajaran CLIS masih kurang untuk meningkatkan kemampuan berpikir kreatif siswa, hal ini dapat dilihat dari nilai rata-rata postest adalah 57,05 dengan kategori kurang kreatif. Faktor-faktor yang mempengaruhi kurangnya kemampuan berpikir kreatif siswa adalah masih kurangnya keterbukaan siswa terhadap pengalaman baru, kemampuan siswa dalam bereksperimen khususnya dalam mengolah data juga masih kurang, penguasaan konsep yang kurang dan keterbatasan waktu mengakibatkan kurang optimalnya proses pembelajaran. Carl Rogersmenyatakan bahwa kemampuan berpikir kreatif seseorang dipengaruhi juga oleh pribadi yang kreatif yang akan mendorong dari dalam untuk berkreasi. Ada tiga kondisi dari pribadi kreatif yaitu (1) Keterbukaan terhadap pengalaman, kemampuan untuk menilai situasi sesuai dengan patokan pribadi seseorang (Internal locus of evaluation). (3) kemampuan untuk bereksperimen, untuk " bermain “ dengan konsep-konsep (Utami, 2012).

\section{Peningkatan kemampuan berpikir kreatif siswa di Palangka Raya setelah diterapkan pendekatan Saintifik dengan menggunakan inkuiri terbimbing}

Peningkatan kemampuan berpikir kreatif siswa di Palangka Raya setelah diterapkan pendekatan Saintifik dengan menggunakan inkuiri terbimbing diukur melalui tes tertulis sebelum dan setelah diterapkan inkuiri terbimbing. Penelitian ini menggunakan sampel sebanyak 24 siswa yaitu siswa kelas VIII- B di SMP Negeri 7 Palangka Raya dengan model inkuiri terbimbing untuk meningkatkan kemampuan berpikir kreatif siswa. Hasil pretest untuk peningkatan berpikir kreatif siswa diperoleh skor rata-rata nilai sebesar 60,46 dan rata-rata nilai posttest peningkatan berpikir kreatif siswa sebesar 73,54. Kemudian rata-rata nilai Gain hasil peningkatan berpikir kreatif siswa sebesar 13,08 dan nilai rata-rata $\mathrm{N}$-gain hasil peningkatan berpikir kreatif siswa sebesar 0,34 dengan kategori sedang yang ditunjukkan pada Gambar 2 berikut. 
Jurnal Pendidikan Fisika dan Keilmuan (JPFK) Vol 3 No 1 Maret 2017, hal 48-56

Avaliable online at : http://e-journal.unipma.ac.id/index.php/JPFK

Print ISSN: 2442-8868, Online ISSN: 2442-904x
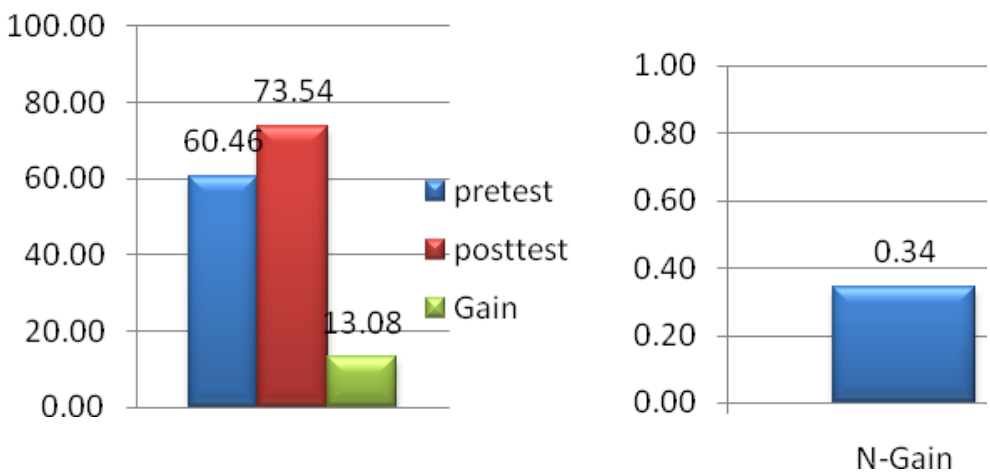

Gambar 2. Diagram Rata-rata nilai Pretest, Postest, Gain, dan N-gain Berpikir Kreatif Siswa diterapkan pendekatan Saintifik dengan menggunakan inkuiri terbimbing

\section{Peningkatan kemampuan berpikir kreatif siswa di Palangka Raya setelah diterapkan pendekatan Saintifik dengan menggunakan metode eksperimen}

Peningkatan kemampuan berpikir kreatif siswa di Palangka Raya setelah diterapkan pendekatan Saintifik dengan menggunakan metode eksperimen diukur melalui tes tertulis sebelum dan setelah diterapkan model eksperimen. Penelitian ini menggunakan sampel sebanyak 28 siswa yaitu siswa kelas VIII- A di
Mts An-Nur Palangka Raya dengan metode eksperimen untuk meningkatkan kemampuan berpikir kreatif siswa. Hasil rata-rata pretest berpikir kreatif adalah 39,69 dengan kategori sangat kurang kreatif dan rata-rata postest berpikir kreatif adalah 63,66 dengan kategori kurang kreatif dan Gain sebesar 23,97. Metode eksperimen pada materi pesawat sederhana, kemampuan berpikir kreatif siswa meningkat yaitu dapat terlihat dari hasil N-Gain rata-rata adalah 0,40 dengan kategori sedang yang ditunjukkan pada Gambar 3 berikut.
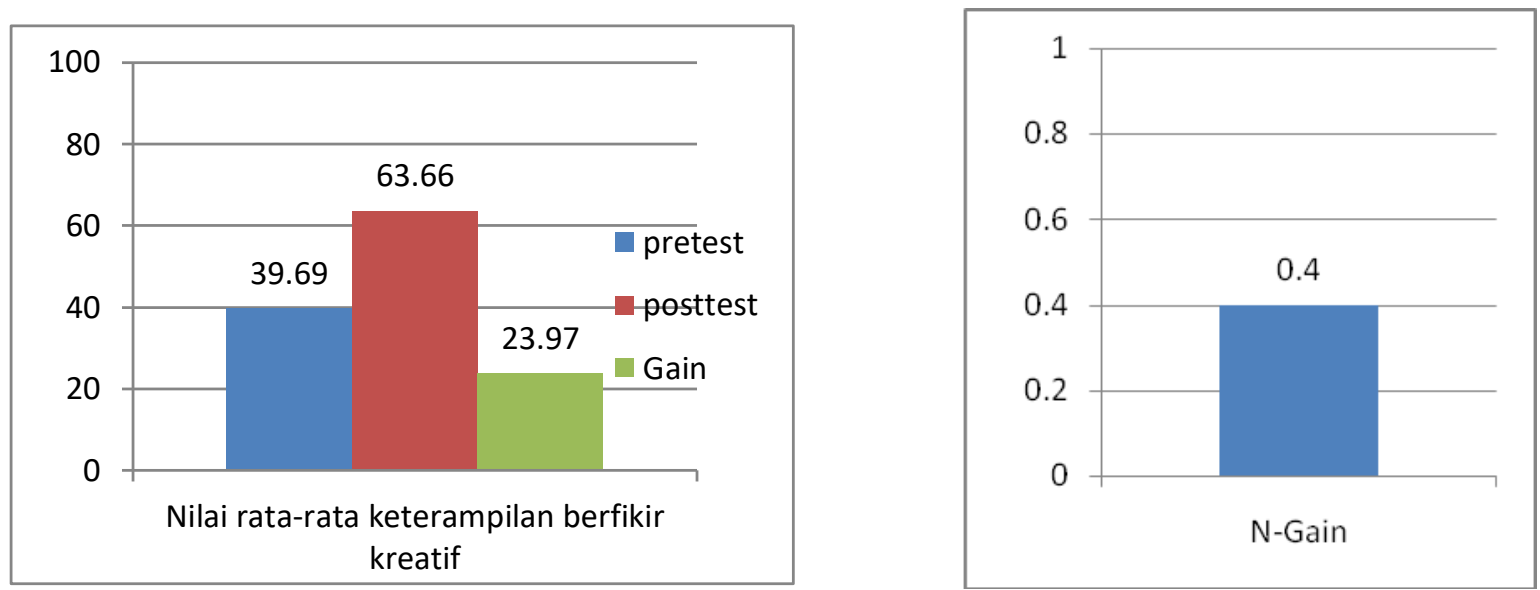

Gambar 3. Diagram Rata-rata nilai Pretest, Postest, Gain, dan N-gain Berpikir Kreatif Siswa diterapkan pendekatan Saintifik dengan menggunakan metode eksperimen

Gambar 3 menunjukkan peningkatan kemampuan berpikir kreatif siswa dengan menggunakan metode eksperimen diperoleh
0,40 dengan kategori sedang. Dengan demikian dapat dikatakan bahwa untuk meningkatkan berfikir kreatif tidak hanya memperhatikan suatu 


\section{Jurnal Pendidikan Fisika dan Keilmuan (JPFK) Vol 3 No 1 Maret 2017, hal 48-56}

Avaliable online at : http://e-journal.unipma.ac.id/index.php/JPFK

Print ISSN: 2442-8868, Online ISSN: 2442-904x

metode pembelajaran tetapi juga perlu dikembangkan motivasi dan pentingnya kreatifitas bawaan siswa yang terus diasah oleh guru disekolah sebagaimana dikatakan Margaret E Bell Graedler bahwa kondisi internal belajar dimana keadaan internal dan proses kognitif siswa merupakan hal yang berhubungan langsung dengan siasat kognitif dalam hal ini adalah berfikir kreatif (Margaret, 1994). (Yusro, 2015) berdasarkan hasil penelitiannya Kreativitas belajar peserta didik dapat diukur dalam aspek kognitif, psikomotorik dan dalam aspek afektif. Aspek kognitif mengacu pada cara berpikir divergen diukur melalui tes kreativitas verbal, sedangkan dari aspek afektif diukur melalui observasi kegiatan pembelajaran yang berlangsung. Hasil pengamatan secara observasi menunjukkan, bahwa selama pembelajaran berlangsung, peserta didik terlihat bersemangat mengikuti proses pembelajaran.

\section{KESIMPULAN}

Hasil penelitian ini dapat disimpulkan peningkatan kemampuan berpikir kreatif siswa di Palangka Raya setelah diterapkan pendekatan Saintifik dengan menggunakan model pembelajaran CLIS (Children's Learning in Science) diperoleh $\mathrm{N}$-Gain rata-rata adalah 0,45 , dengan inkuiri terbimbing diperoleh $\mathrm{N}$-gain ratarata sebesar 0,34, dengan metode eksperimen diperoleh $\mathrm{N}$-gain 0,40 pada pembelajaran fisika pokok bahasan pesawat sederhana Pada Sekolah Menengah Pertama di Palangka Raya dengan kategori sedang.

Berdasarkan kesimpulan penelitian, dapat disarankan beberapa hal sebagai berikut: (1) Untuk penelitian selanjutnya diharapkan peneliti terlebih dahulu melakukan observasi awal terhadap waktu belajar siswa dan kegiatankegiatan yang ada di sekolah yang mungkin dapat menggangu penelitian. (2) Untuk penelitian selanjutnya sebelum menggunakan pendekatan dan metode mengajar tertentu dalam penelitian, sebaiknya metode dan pendekatan tersebut diuji cobakan terlebih dahulu. Sehingga saat penelitian berlangsung siswa sudah terbiasa dengan metode tersebut. Hal ini penting untuk memperoleh hasil penelitian sesuai yang diharapkan. (3).Untuk penelitian selanjutnya yang bertujuan untuk mengukur berpikir kreatif siswa agar memperhatikan kesesuaian indikator dengan soal dan hendaknya mencari referensi yang memuat contoh indikator beserta contoh soalnya.(4) Guru hendaknya memperhatikan jam pelajaran yang sesuai dengan kesulitan mata pelajaran yang akan dipelajari oleh siswa.

\section{DAFTAR PUSTAKA}

Astupura, D. A., \& Yuliani, H. (2016). Korelasi Model Pembelajaran Learning Cycle Terhadap Motivasi Dan Keterampilan Proses Sains Pada Materi Pokok Cahaya. EDU SAINS, 3(2).

Astupura, D. A., \& Yuliani, H. (2016). Penerapan Model Pembelajaran Learning Cycle Terhadap Motivasi Dan Keterampilan Proses Sains Pada Materi Pokok Cahaya. EDU SAINS, 4(1).

Furchan, A. (2007). Pengajaran Penelitian dalam Pendidikan, Yogyakarta: Pustaka Pelajar..

Ganijanti, A. (2002). Seri Fisika Dasar Mekanika. Jakarta: Salemba Teknika.

Hamzah, B.Uno dan Nurdin, Mohamad. (2014). Belajar Dengan Pendekatan PAIKEM: Pembelajaran Aktif, Inovatif, Lingkungan, Kreatif, Efektif, Menarik. Jakarta: Bumi Aksara.

Marjan, J. (2014)."Pengaruh Pembelajaran Pendekatan Saintifik Terhadap Hasil Belajar Biologi dan Keterampilan Proses Sains Siswa MA Mu'allimat NW Pancor Selong Kabupaten Lombok Timur Nusa Tenggara Barat", e-Journal Program Pascasarjana Universitas Pendidikan Ganesha Program Studi IPA, Vol.4.

Johnson, E. B. (2011). “CTL”. Bandung : Kaifa.

Sari, R. K. (2015). Perbandingan model pembelajaran kooperatif tipe Number Head 


\section{Jurnal Pendidikan Fisika dan Keilmuan (JPFK) Vol 3 No 1 Maret 2017, hal 48-56}

Avaliable online at : http://e-journal.unipma.ac.id/index.php/JPFK

Print ISSN: 2442-8868, Online ISSN: 2442-904x

Together (NHT) dan Student Team Achievement Division (STAD) ditinjau dari sikap ilmiah siswa dalam pokok bahasan suhu dan kalor di Kelas X semester II SMA Negeri 1 Palangka Raya Tahun Ajaran 2014/2015 (Doctoral dissertation, IAIN Palangka Raya).

Margaret, E.B.G. (1994). Belajar dan Membelajarkan, Jakarta : Raja Grafindo.

Martono, N. (2010). Metode Penelitian Kuantitatif Analisis Isi dan Analisis Data Sekunder, Jakarta : Raja Grafindo Persada.

Munandar, U. (2012). Pengembangan Kreativitas Anak Berbakat. Jakarta:Rineka Cipta.

Ngalimun, dkk. (2013). Strategi dan Model Pembelajaran Berbasis PAIKEM, Banjarmasin : Pustaka Banua.

Nursito. (2000). Kiat Menggali Kreativitas.Yokyakarta: Mitra Gama Widya

Palaila, A. (2007). Model Inkuiri Terbimbing untuk Meningkatkan Penguasaan Konsep dan Berfikir Kreatif, Bandung : Sekolah Pasca sarjana Universitas Pendidikan Indonesia.

Riyanto, Y. (2010). Paradigma Baru Pembelajaran. Surabaya: Kencana Prenada Media Group.

Sani, R. A. (2014). Untuk Implementasi Kurikulum 2013. Jakarta: Bumi Aksara.

Saregar, A. (2016). Pembelajaran Pengantar Fisika Kuantum dengan Media PhET Simulation dan LKM Melalui Pendekatan Saintifik: Dampak pada Minat dan Penguasaan Konsep Mahasiswa. Jurnal Ilmiah Pendidikan Fisika AlBiruni Vol 5 No 1, 53-60.

Sugiyono. (2007). Metode Penelitian Pendidikan Pendekatan
Kuantitatif,Kualitatif, dan $R \& D$, Bandung: Alfabeta.

Toharudin, U. (2011). Membangun Literasi Sains Peserta Didik. Bandung: Humaniora.

Wawancara guru mata pelajaran Fisika MTs Annur Palangka Raya (tanggal 25/09/2014).

Wawancara siswa kelas VIII MTs An-nur Palangka Raya (tanggal 25/09/2014).

Yuliani, H. (2012). Pembelajaran Fisika dengan Pendekatan Keterampilan Proses dengan Metode Eksperimen dan Demonstrasi Ditinjau dari Sikap Ilmiah dan Kemampuan Analisis. INKUIRI Vol 1 No.3,207-216

Yusro, A. (2015). Pengembangan Perangkat Pembelajaran Fisika Berbasis SETS Untuk Meningkatkan Kemampuan Berpikir Kreatif Siswa. JURNAL PENDIDIKAN FISIKA DAN KEILMUAN (JPFK), 1(2), 61-66. 